Case Report / Olgu Sunumu

\title{
VESTIBULAR NEURONITIS: A CASE REPORT
}

Vestibüler Nörinit: Olgu Sunumu

\author{
Deniz Ŭgur CENGİZ1 (D) Mehmet TAN 2 (D) Zeynep SAĞLAM ${ }^{3}$ (D) Tuba BAYINDIR ${ }^{4}$ (D) \\ ${ }^{1}$ İnönü Üniversitesi, Sağlık Bilimleri Fakültesi, Malatya \\ ${ }^{2,4}$ Inönü Üniversitesi, Turgut Özal Tıp Merkezi, Malatya \\ ${ }^{3}$ Akdeniz Üniversitesi, Sağlık Bilimleri Enstitüsü, Antalya
}

Geliş Tarihi/Received: 01.04.2020 $\quad$ Kabul Tarihi/Accepted: 10.04.2020 $\quad$ Yayım Tarihi/Published: 26.04.2020

\begin{abstract}
Vestibular neuronitis (VN) is a selective, acute or subacute inflammation of the vestibular nerve. The typical VN clinical picture is generally characterized by signs of isolated vestibular syndrome following a previous upper respiratory tract infection and does not present acoustic symptoms or signs such as hearing impairment or tinnitus at this stage. Patients may also complain of oscillopsia and imbalance. The clinical picture peaks within 1-2 days and resolves in a few weeks. Vestibular neuronitis mostly involves the superior vestibular nerve. Superior vestibular nerve fibers innervate the superior semicircular canal, the lateral semicircular canal, and the utricle.
\end{abstract}

Keywords: Vertigo, superior vestibular nerve, vestibular neuronitis

\section{ÖZ}

Vestibülernörinit (VN), vestibüler sinirin selektif, akutya da subakut inflamasyonudur. Tipik VN klinik tablosu, genellikle geçirilmiş bir üst solunum yolu infeksiyonunu takiben izole vestibüler sendrom bulguları ile karakterizedir ve bu süreçte işitme azlığıya da kulak çınlaması gibi akustik semptom ve bulgu vermemektedir. Ayrıca hastalar osilopsi ve dengesizlikten de yakınabilirler. Klinik tablo 1-2 gün içinde pik yapar ve birkaç haftada düzelir. Vestibüler nörinit çoğunlukla süperior vestibüler siniri tutmaktadır. Süperior vestibüler sinir; süperior semisirküler kanal, lateral semsirküler kanal ve utrikülü inerve etmektedir.

Anahtar Kelimeler: Vertigo, süperior vestibüler sinir, vestibüler nörinit 


\section{INTRODUCTION}

Vestibular neuronitis is a selective, acute or subacute inflammation of the vestibular nerve. It is the 3rd common cause of peripheral vertigo after benign paroxysmal positional vertigo and Meniere's disease. It constitutes about $7-10 \%$ of all vertigo cases. Vestibular neuronitis shows clinically isolated vestibular signs. Acoustic signs such as hearing loss or tinnitus are not among clinical signs of this disease (Jeong, Kim \& Kim, 2013). Vertigo symptom of vestibular neuronitis manifests itself in a very severe way. This symptom persists for days and weeks and even months in some cases. The prognosis of the disease shows a slow healing process. This process has been observed to continue for up to 18 months with the complaint of imbalance in some cases (Tusa, 2001; Derebery, 1999). In vestibular neuronitis, in most cases, the superior vestibular branch of the vestibular nerve is affected due to anatomical and physiological reasons, whereas in some cases, the inferior vestibular branch is involved. Superior vestibular nerve fibers innervate the superior semicircular canal, the lateral semicircular canal, and the utricle. For this reason, in most cases, pathological findings are obtained in vestibular test batteries that examine these vestibular end-organs (Jeong, Kim \& Kim, 2013; Halmagyi, Aw, Karlberg, Curthoys \& Todd, 2002; Kim \& Kim, 2012).

In this study, a patient diagnosed with vestibular neuronitis, who had consistent clinical examination, hearing and balance results, was presented in the light of the literature.

\section{A CASE REPORT}

Written permission was obtained from the patient for all procedures and scientific presentations. A 44-year-old male who presented to the emergency department with complaints of sudden severe dizziness, nausea and vomiting approximately 1 month earlier while at work was evaluated. The patient was given vestibular suppressant treatment intravenously and was relieved symptomatically. Then, the patient was referred to the Otorhinolaryngology Department Polyclinic of the Faculty of Medicine at İnönü University. After the patient was examined there, he was started to be given Betahistine dihydrochloride $24 \mathrm{mg}$ tablet $2 \times 2$ and Piracetam $800 \mathrm{mg}$ tablet $3 \times 800 \mathrm{mg}$. At the end of one month of treatment, the patient continued to feel dizziness. So, the vestibular suppressant treatment was discontinued, and he was referred to the audiology unit for vestibular tests. It was noted in the anamnesis that dizziness was very severeduring the first six hours following the attack that the patient had, accompanied by sweating and headache; he could not stand, and could not get out of bed for three days. Dizziness was in the form of "pushing, feeling of fall, and spinning of 
the surroundings." The patient said he began to heal three days after the first attack, his dizziness began to decrease, and he could stand unsupported. The patient continued to have a feeling of dizziness and complaints of tinnitus in his left ear. The patient stated that he did not experience a dizziness as severe as the first attack during or after the medical treatment, but continued to have complaints about balance. He had a history of upper respiratory tract infection (URTI) about a month before the vertigo attack. It was also noted that he was diagnosed with migraine 3 years earlier. Radiological evaluations showed no pathology in both computed tomography (CT) and magnetic resonance imaging (MRI).

The patient's audiological evaluation revealed an age-related decrease in $4-8 \mathrm{kHz}$ band in the left ear, but bilaterally normal hearing. Speech recognition threshold (SRT) and speech discrimination (SD) scores were measured to be within bilateral normal limits. Bilateral Type A tympanogram was observed in the immitansmetric examination of the patient, and his ipsilateral reflexes were found to be bilaterally normal. Signal-to-noise ratio (SNR) was determined to be over $3 \mathrm{~dB}$ at all frequencies bilaterally in the transient evoked otoacoustic emissions (TEOAEs) test that the patient underwent. When the patient's balance was assessed, his tendency to turn left 45 degrees was observed in Unterberger's test and his tendency to fall to the left was observed in tandem gait test, which was the bedside tests performed while the patient's eyes were closed. There were no pathologic findings in the dysdiadochokinesia test. The patient did not show nystagmus in the gaze test. The oculomotor test results of the patient were observed to be normal. Spontaneous nystagmus test revealed a $5 \%$ sight-beating nystagmus in the unfixed stage, and a head shake test showed an $8 \%$ s rightbeating nystagmus. In positional tests, spontaneous nystagmus that did not change direction with position was observed.

The caloric test was calculated according to Jongkee's formula with a $5 \%$ s nystagmus. The patient's left ear response was detected to be $31 \%$ weaker than the right ear. Lateral superiority parameter was found to be $30 \%$ (Figure 1). 


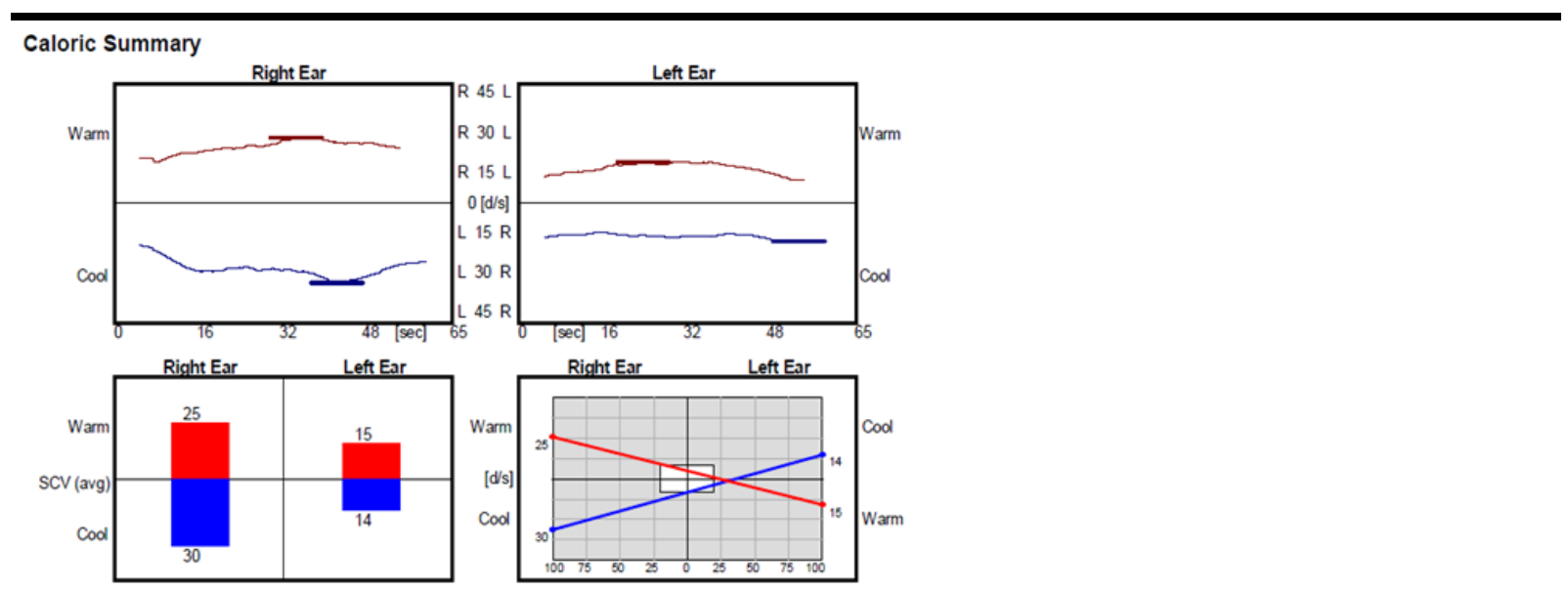

Figure 1: Left ear response is 31\% weaker, Left beating response is 30\% stronger

In the lateral channels, $22 \%$ asymmetry was observed based on a video head impulse test (VHIT). Low gain, asymmetry and overt saccades were detected when the left lateral canal was stimulated. The left ear was found to have weakness. The left anterior right posterior (LARP) test for vertical canals showed 19\% asymmetry. Overt saccades and low gain were detected when the left anterior canal was stimulated. Normal results were detected in the right anterior left posterior (RALP) test (Figure 2).
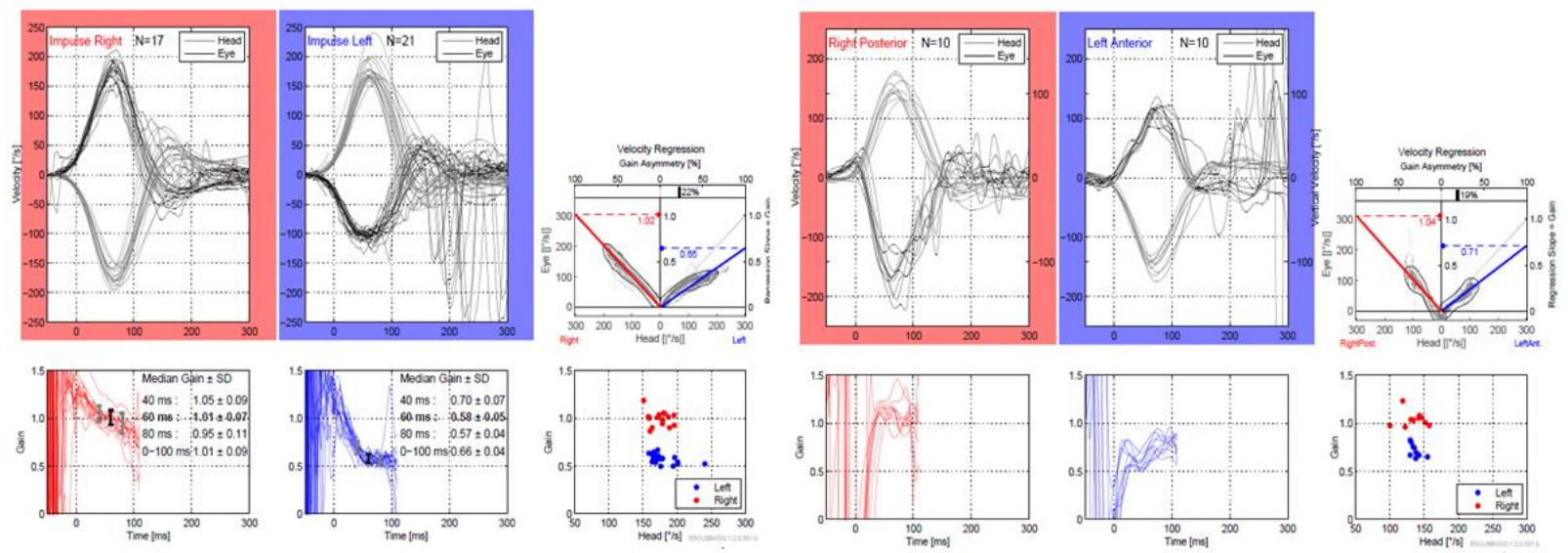

Figure 2: Left lateral response is $22 \%$ weaker; Left anterior response is $19 \%$ weaker

P1 and N1 waves were obtained within bilateral normal limits in the cervical vestibularevoked myogenic potential (cVEMP) test. N1 and P1 waves were observed within normal limits of the right ear in the ocular vestibular-evoked myogenic potential (oVEMP) test. P1 and N1 waves could not be obtained in the left ear (Figure 3). 


\section{VEMP: oVEMP (ocular)}

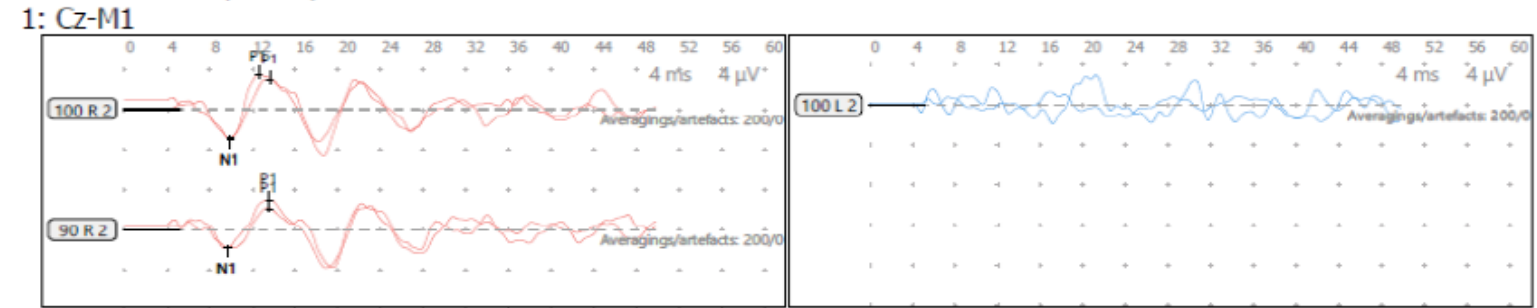

Figure 3: Normal oVEMP was detected on the right side; oVEMP absence of response was the case on the left side

Based on the results obtained from the patient's anamnesis and hearing and balance test batteries, it was considered that he had peripheral vestibular pathology affecting the superior vestibular nerve in the left ear. The patient was diagnosed with vestibular neuronitis by the ENT physician. Written permission was obtained from the patient for all procedures and scientific presentations.

\section{DISCUSSION}

Peripheral vestibular diseases are some of the most common and important disorders in otology/neurotology. BPPV, Meniere's disease and vestibular neuronitis are some of the most common peripheral vestibular disorders in society.

Vertigo complaints of patients with BPPV last a very short amount of time (for seconds or minutes). Various maneuvers are performed for the diagnosis and treatment of the disease (Ardıç \& Tümkaya, 2014). Meniere's disease is typically characterized by tinnitus, hearing loss, ear fullness and spontaneous vertigo attacks (Nathan, Pierce \& Patrick, 2012; Michael, Marianne \& Thomas, 2013). It can be diagnosed through clinical findings, pure-tone audiometry, caloric testing, VEMP and histopathology (Ardıç \& Tümkaya, 2014). Vestibular neuronitis, however, is characterized by acute, isolated and spontaneous unilateral vestibular loss and involves dizziness that occurs for days without hearing loss. It is usually diagnosed clinically during the acute period. In the advanced period, caloric testing and vestibularevoked myogenic potentials (VEMPs) offer useful information (Jeong, Kim \& Kim, 2013; Ardıç \& Tümkaya, 2014).

In vestibular neuronitis, different results may be observed depending on the localization of the vestibular nerve. In rare inferior vestibular neuronitis, torsional nystagmus is seen during examination. In caloric testing, caloric test results are normal due to the fact that only the lateral canal is stimulated in this test, as well as the results of VHIT in which lateral and anterior channels are stimulated. cVEMP responses are weak (Jeong, Kim \& Kim, 2013; Colebatch, Rosengren \& Welgampola, 2016). Horizontal-rotatory spontaneous nystagmus, 
which has a fast phase in the opposite direction of the lesion, is observed during the examination of the superior vestibular neuronitis, which is more common than inferior vestibular neuronitis. Pathological findings are observed as a result of caloric testing, in which lateral channels are stimulated, and in results of VHIT test where anterior and lateral channels are stimulated. Absence of response or weakened responses are observed in oVEMP responses, whereas responses obtained from cVEMP are the same (Tusa, 2001; Derebery, 1999; Colebatch, Rosengren \& Welgampola, 2016).

In this case report; O-VEMP and C-VEMP findings (Soo Shin, Young Oh, Soo Kim, Woo Kim, Wook Seo, Lee \& Park, 2012), caloric test findings (Halmagyi, Aw, Karlberg, Curthoys \& Todd, 2002) and VHIT findings (Tjernström, Nyström \& Magnusson, 2012) of the patient with superior vestibular neuronitis show similarity with the studies in the literature.

In peripheral vestibular disorders, the main complaint is vertigo, which is a subjective condition. For this reason, it becomes difficult for patients to explain their complaints and for the physician to understand their complaints. For a differential diagnosis, hearing and balance tests must be carried out in addition to a good anamnesis. Vestibular neuronitis is differentiated from peripheral vestibular disorders such as Meniere's disease and labyrinthitis as its hearing tests are normal. It is differentiated from BPPV because in vestibular neuronitis, no nystagmus that changes direction is observed in different positions, and dizziness lasts for hours (Jeong, Kim \& Kim, 2013).

The case we presented in our study was observed to have classical signs of vestibular neuronitis. And additionally, hearing and balance test results, which are important in the differential diagnosis, were added to the study. It was observed that the test results we examined in the study and those used in our clinic were compatible. Carrying out such studies in the clinic from time to time is of great importance for reconsidering test batteries, forming normative data, and improving the accumulation of clinical knowledge.

\section{REFERENCES}

Ardıç FN, Tümkaya F. Periferik Vestibüler hastalıklarda kanıta dayalı ilaç tedavisi, Vestibular Medical Treatment, Turk Arch Otolaryngol, 2014;52:61-6.

Colebatch JG, Rosengren SM, Welgampola MS. Vestibular-evoked myogenic potentials, Handbook of Clinical Neurology, (3rd series) Neuro-Otology, 2016;137:133-55.

Derebery MJ. The diagnosis and treatment of dizziness, Med Clin of North Am, 1999;83(1):163-77.

Halmagyi GM, Aw ST, Karlberg M, Curthoys IS, Todd MJ. Inferior vestibular neuronitis, Ann. N.Y. Acad. Sci., 2002;956:306-313.

Jeong SH, Kim HJ, Kim JS. Vestibular neuritis, Semin Neurol, 2013;33(3):185-94. 
Kim JS, Kim HJ. Inferior vestibular neuritis, J Neurol, 2012;259:1553-1560.

Michael S, Marianne D, Thomas B. The treatment and natural course of peripheral and central vertigo, Dtsch ArzteblInt, 2013;110:505-16.

Nathan E, Pierce NE, Patrick J. Antonelli Endolymphatic hydrops perspectives, Curr Opin Otolaryngol Head Neck Surg, 2012;20:416-419.

Soo Shin B, Young Oh S, Soo Kim J, Woo Kim T, Wook Seo M, Lee H, Ae Park Y. Cervical and ocular vestibular-evoked myogenic potentials in acute vestibular neuritis Clinical, Neurophysiology Clinical Neurophysiology, 2012;123:369-375.

Tjernström F, Nyström A, Magnusson M. How to uncover the covert saccade during the head impulse test, Otol Neurotol, 2012;33:1583-5.

Tusa RJ. Vertigo, Neurologic Clinics, 2001;19(1):23-55. 